\title{
ABOUT CAREER ORIENTATION OF MODERN STUDENTS: FOREIGN AND DOMESTIC APPROACHES
}

\author{
Andrii Kryzhanovskyi \\ $\mathrm{PhD}$, Assistant at the Department of Prosthetic Dentistry, \\ State institution "Dnipropetrovsk Medical Academy of the Ministry of Health of Ukraine", Ukraine \\ e-mail: andrei.kr@i.ua, orcid.org/0000-0001-9226-9012
}

\section{Summary}

The article considers the problem of career and career orientation of modern students in domestic and foreign scientific psychological and pedagogical literature. It is emphasized that the concepts of "career" and "competition" are etymologically related concepts. It is noted that a successful career involves a competitive personality. Three integral characteristics of a competitive personality are characterized: orientation, competence, flexibility. It is noted that the mental development of a cultured person occurs through the appropriation of social consciousness - social ideas, knowledge, language, ideals, norms, traditions, assessments, which are stored in the culture of the people and which in the transition to the internal plan form the psyche of a particular person. It is proved that in senior courses a professional identity is formed and the final decision is made whether to connect one's future destiny with the chosen profession or not. Based on the results of the theoretical analysis of career understanding issues, foreign and domestic researchers have identified the main approaches to career understanding: semantic, role, value, procedural, status, personal-professional, biographical, acmeological. It is emphasized that the process of formation of professionalism throughout the life of students is self-realization and the formation of its subjectivity. It is noted that the most popular foreign theory of professional development was the model of D. Super.

Keywords: career, career orientations, successful and well-off person, professional development, career path of students.

\section{DOI: https://doi.org/10.23856/3820}

\section{Introduction}

The problem of human implementation of strategies for self-development in the profession and career in a qualitative transformation of modern society becomes extremely relevant because it involves a choice based on awareness of the values of life, including professional and career ways that give meaning and balance in a changing world.

Modern conditions for the development of Ukrainian society have contributed to the value reorientation associated with the advent of the "culture of success" what is typical for Western countries. In the new Ukrainian society, "making a career" has become not only possible, but also necessary to be considered and consider yourself as a successful person. The image of a successful wealthy person, promoted in the mass media and at the same time does not have its own cultural and historical basis, causes modern youth to have a high status and easy money, which is not supported by the desire to develop relevant professional competencies In this regard, it is interesting to analyze how modern students present their career development, to what extent young people are aware of their own career strategies.

The purpose of the article is a theoretical analysis of the scientific literature on the problem of career and career orientation in modern domestic and foreign psychology. 
The issues of career construction and development are currently sufficiently studied, there are a variety of approaches to understanding the phenomenon of career, stages of its development (Zeer, 1988), (Klimov, 1996), (Ladanov, 1997) and others. Factors that contribute to the successful development of an individual career are studied (Bogatyreva, 2009), (Mogilevkin, 1998), (Hammer, 2008: 147).

In career research, much attention is paid to such related concepts as work motivation, professional activity and career (R.A. Noe, A.W. Noe, J.A. Bachuber, specialization (M.C. White, M. Smith, T. Barlett), subjective career success (R. Ellis, H.G. Heneman, R.N. Mirvis, D.T. Hall) and others (Shchelokova, 2012: 24).

\section{Career as a socio-psychological phenomenon}

"Career orientations" currently means a system of personal dispositions in relation to career and work, which is manifested through values, attitudes and interests that encourage the development of activities in a certain direction (Melnikova, 2012: 275).

In relation to his career, a person can also act as a subject and an object. The person as "object of career" implements the career passively - according to the samples presented to it, thus rather the person masters means of the advancement, and "career masters the person" (Krichevsky, 2012). The latter is understood as careerism: the pursuit of personal success in work, motivated solely by a personal desire for well-being. In other words, when we talk about a person as an object of career, we mean: a) his passivity in planning and building a career, inability to manage his career development; b) the phenomenon of "careerism", "career pursuit", when the values of material well-being and promotion come to the fore and ignore the values of development in other areas - personal (need for self-actualization), professional (competence), public (desire to benefit society).

\section{The concept of "career": foreign approaches to the study of career}

There is no coincidence that "career" and "competition" are etymologically related concepts. The concept of "career" comes from Latin. "Currere" - to run, and "competition" - from "concurrere" - to run together, in one direction, to compete (Bash, Bobrova, 1999). Both concepts have a pronounced social character. A successful career involves a competitive personality. L.M. Mitina names three integral characteristics of a competitive personality: orientation, competence, flexibility (Mitina, 2009: 10). Orientation is understood as a system of emotional and value relations that define the dominant motives of personality, competence - as knowledge, skills, abilities, methods of implementation and communicative qualities, flexibility - as the quality of intelligence, behavior, emotional manifestations.

According to the cultural-historical paradigm (Moskovichi, Potebnya, 1993), (Shpeta, Ponomarev, 1983), the process of understanding life, choosing values and building a career is not only the result of individual development, but mediated by social ideas, values, norms and standards transmitted. society and reference groups. Their content is determined by the historical stage, culture and social attitudes of the society in which the individual is. As emphasized by one of the representatives of the cultural-historical approach O.O. Potebnya (Potebnya, 1993), the mental development of a cultured person occurs by assigning social consciousness - social ideas, knowledge, language, ideals, norms, traditions, assessments, which are preserved in the culture of the people and which in transition to the internal plan form the psyche of a particular person. According to G.G. Shpeta (Ponomarev, 1983), humanity in the process of its development has created a new, socio-cultural world that exists in addition to the natural world, and 
human social existence transforms it into a social personality, whose behavior is endowed with social meaning and serves as a sign for other people and for himself.

According to the concept of D. Super, each person has abilities, motivations, motives and values, which he cannot give up when making a career choice. In this regard, D. Super was one of the first who spoke about career orientations as the meanings that a person seeks to realize in the choice and construction of his career, and a set of attitudes associated with professional experience and professional activity (Bogatyreva, 2009). According to D. Super, a person's attempt to answer the question: "Who am I?" is seen in professional preferences and the chosen type of career. At the same time, the individual often realizes his career orientations unconsciously (Hammer, 2008: 149), (Horne, 1997).

D. Super developed the concept of periodization of professional development, which is based on the periodization of life according to E. Erickson and S. Buhler. D. Super believes that during professional self-determination a person develops and refines his professional self-concept, and offers a five-step model of professional development, which has the following stages: 1. Stage of awakening (0-14 years old), during which the self-concept develops through identification with significant adults; 2. Research stage (15-24 years old), where a person tries to test himself in different roles while focusing on his real professional opportunities; 3 . The stage of consolidation, or strengthening (25-44 years old) is characterized by the desire to ensure a stable personal position in the found professional field; 4 . At the stage of preservation of the achieved (46-64 years old) professional development goes in one certain direction, without going beyond the found professional field; 5 . At the stage of recession (after 65 years old) there is a development of new roles: partial participation in professional life, observation of professional activities of other people (Hammer, 2008: 149), (Horne, 1997). Along with the concept of staging D. Super introduces the concept of professional maturity, which refers to the individual, whose behavior corresponds to the tasks of professional development, characteristic of this age. To determine professional maturity, the method "Career Maturity Inventory" was created, as well as a number of similar methods (Kondakov, 1989: 160).

Among foreign concepts, one of the most popular in our country is also the typological theory of D. Holland, according to which the process of professional development involves, firstly, the definition of the individual personality type, to which he belongs, and secondly, finding a professional field corresponding to this type, and thirdly, the choice of one of the four qualification levels of this professional field, which is determined by the development of intelligence and self-esteem. The main attention in the author's ideas is paid to the description of personal types, such as: realistic, intellectual, social, adaptive, aesthetic, entrepreneurial. However, as noted by I.M. Kondakov and A.V. Sukharev (Kondakov, Sukharev, 1989: 164), the most vulnerable point in typological theory is, firstly, the principle on the basis of which the construction of types, and secondly, the fact that the real individual often does not correspond to any of the personality types, related to certain professional fields.

According to E. Shane's theory of "career anchors" (Hacken, 1980), there are external and internal factors that contribute to career development. External factors include the socio-economic situation, professional environment, organizational culture of the company and others. To the internal - motivation, self-esteem, level of demands, state of health. O.O. Bogatyreva complements the list of internal factors with the concept of self-efficacy, understanding it as a set of "individual psychological features that characterize the perception of their own competence, efficiency and personal influence" (Bogatyreva, 2009: 56). When a person perceives himself as capable of success and predicts it in his current activities, the bar of his goals increases, thus stimulating the mobilization and support of the efforts is necessary for career growth. 


\section{Domestic approaches to career study}

As noted by R.L. Krychevsky (Krychevsky, 2013), compared with foreign researchers, domestic authors reveal in more detail the psychological meaning of career. Thus, O.O. Bodalov and L.L. Rudkevich in psychological components of the concept of "career" consider: the nature of the goals set by the person, engaging in socially significant activities; system of motivating factors; the degree of actualization of the specialist's abilities.

According to Yu.P. Povarenkova, in the third year of study at a higher educational institution the student's personality as a subject of educational and academic activity is finally formed, and in the fourth (under the influence of industrial practice) - as a subject of professional activity. That is, in senior courses (4-5) a professional identity is formed and the final decision is made whether to link their future destiny with the chosen profession or not.

Of great importance in the psychology of work, profession and career are the ideas of E.F. Zeer (Zeer, 1988), based on the understanding of the individual as a subject of social relations and activity. In the structure of personality as a subject of professional activity E.F. Zeer distinguishes 4 components:

1. Orientation, which is characterized by a system of dominant needs and motives. E.F. Zeer identifies the following components of professional orientation: motives (intentions, interests, inclinations, ideals), values (meaning of work, wages, welfare, qualifications, career, social status, etc.). Professional position (attitude to the profession, personal settings, expectations and readiness for professional development), socio-professional status;

2. Professional competence, the main components of which are: socio-legal, special, personal, auto and extreme competence;

3. The system of professionally important qualities that determine productivity. They are multifunctional and differ in the originality of their composition in each profession;

4. Professionally significant psychophysiological properties, the development of which occurs in the process of mastering the activity. Examples of these qualities are visual-motor coordination, outlook, neuroticism, extraversion, reactivity, etc.

In the direction of personality-development approach, L.M. Mitina deals with the problems of professional development of personality (Mitina, 2009). According to L.M. Mitina, professional development is "growth, formation, integration and realization in professional work of professionally significant personal qualities and abilities, professional knowledge and skills, but, most importantly, as an active qualitative transformation of a person's inner world, which leads to a fundamentally new system and way of life - creative self-realization in the profession" (Mitina, 2009: 11). From these standpoints, professional development (self-development) is a process of constructing a person's subjectivity, his image of the world, his self-concept, himself in the profession and goes through three stages: self-determination, self-expression and self-realization.

O.E. Ilgunova, studying the dynamics of the formation of professional styles at different stages of the career of civil servants, came to the conclusion that age and professional experience alone do not provide a consistent and positive development of professionalism (Ilgunova, 2005).

The most famous domestic periodization of human development as a subject of labor was proposed by E.L. Klimov (Klimov, 1996). He distinguishes two stages in human development: pre-professional and professional development. The scientist identifies the following stages of professional development: pre-games, games, mastering educational activities, "options", adept, adapter, intern, master, authority, mentor. 
In acmeological concept E.F. Zeer (Zeer, 1988) speaks of the "life path" of a professional, so it includes the main stages from its beginning to the top and contains five stages of professionalization:

1. "Option" - the choice of profession taking into account individual, personal and situational characteristics;

2. Vocational training - acquisition of professional knowledge, skills and abilities;

3. Professional adaptation - entering the profession, mastering the social role, professional self-determination, formation of qualities and experience;

4. Professionalization - the formation of positions, integration of personal and professional qualities, performance of duties;

5. Professional skill - the realization of personality in professional activities.

O.E. Ilgunova identifies two age stages of formation of professionalism and styles of professional activity of subjects without a pronounced stable "plateau", two qualitatively different parts of the career path. The first stage of "spontaneous formation" (up to 35-40 years old) is determined by young age, natural talent, the role of loved ones. The second stage of "purposeful formation" of a professional career (from 40-45 years old) is determined by the ability to personal development, complete mastery of human resources, skills to regulate behavior and activities, full self-realization in various spheres of life, becoming an active subject of life (Ilgunova, 2005).

As noted by Yu.P. Kukharchuk, that most periodizations have a number of limitations: use as a temporary parameter only chronological age and do not take into account professional experience, are characterized by a reduction in the content of professional development, for example, reduce its essence to the development of professional self-knowledge (D. Super) and do not take into account professional abilities, motivation of the subject of labor (Povarenkov, 2009). Yu.P. Povarenkov proposes to increase the attention of researchers to the allocation of levels in the periodization of professional development: stages, periods and phases. The leading criterion for the selection of the stage is the acceptance of the subject of the social situation of professional development as a guide to action. The author identifies 5 stages: pre-professional development, search and choice of profession ("option"), vocational training, independent professional activity, post-professional development. The boundaries between the phases are blurred, and they by themselves are heterogeneous and include periods of development. The basis for the allocation of the period is to clarify the situation of professional development and specify the tasks of professional development. As part of the stage Yu.P. Kukharchuk distinguishes 3 periods: adaptation and formation of resources to solve a new task, the period of solving the main task of professional development at this stage, preparation for the transition to a new stage of development. In turn, each of the periods is divided into several phases, for example, the period of adaptation into such phases as: the use of old tools, finding ways and means of adaptation, the process of adaptation, reaching the required level of adaptation (Povarenkov, 2009).

Based on the results of the theoretical analysis of the issues of career understanding by foreign and domestic researchers, the main approaches to career understanding can be identified as:

1. Meaningful: career as a field of occupation, profession (military career, etc.);

2. Procedural approach: career as advancement, movement forward, dynamic process, sequence, dynamics of states and activity of the individual in labor activity. There are two lines of such promotion:

a) career as "professional advancement, professional growth, transition from one degree of professionalism to another" (Markova, 1996: 65), as "the gradual development of abilities and functions of man as a professional" (Ilgunova, 2005: 57); 
b) career as "job promotion, where the achievement of a certain social status, occupation of a certain position comes to the fore" (Markova, 1996: 65).

A person can build a career both professionally and professionally, which may not coincide (Markova, 1996).

3. Status approach: career as an indicator of the success of the individual: career as "the path to success, a prominent position in society, in the service field, as well as the achievement of such a position" as a person's performance and social status (Krichevsky, 2013).

4. Role approach: career as a social role corresponding to social expectations (performance standards), as a sequence and combination of roles that a person performs throughout life (D. Super (Hammer, 2008)).

5. Value approach: career as a consistency of personal and social needs, goals, values, interests. Thus, G.B. Mikhailov understands career as such movement of the subject on service in professional improvement which corresponds to its value orientations and at the same time fully satisfies interests of society. As part of the value approach, career is associated with socially significant activities of the individual in society (Krichevsky, 2013).

6. Personal-professional approach: career as a process of professional self-determination, which alternates the choices that are based on the "self-concept" of the individual - a relatively holistic education, gradually changes as a person grows up (N.S. Pryazhnikov, D. Super (Hammer, 2008: 153)).

\section{Biographical approach:}

a) in a narrow sense: career as an individual career, its activities, expressed in professional or official form (Krichevsky, 2013);

b) in a broad sense: career as "life in general", the way of man's life, as "active movement of man in the development and improvement of lifestyle, which ensures its stability in the flow of social life". In this sense, a career goes beyond professional and employment (Kibanov, 1997).

8. Acmeological approach: career as a process of human self-realization, his capabilities in professional activities, achieving personal "acme" (Ladanov, 1997), (Mogilevkin, 1998), career as self-actualization in professional activities, creative self-realization in profession (Mitina, 2009: 12), career as a way to achieve goals and results in the basic form of personal self-expression (Krichevsky, 2013).

\section{Conclusions and suggestions}

The analysis of scientific research has shown that the problem of career and career orientation of students is sufficiently studied in modern domestic and foreign literature. High professionalism is an important, but not the only determinant of successful professional and personal development associated with successful career advancement. As noted by R.L. Krichevsky that professionalism is a special qualitative characteristic of the individual: only realizing himself as a subject of life and his life, including professional and career path, a person is a real creator of his "acme". It is emphasized that the process of formation of professionalism throughout the life of students is self-realization and the formation of its subjectivity.

It is important to note that the most popular foreign theory of professional development was the model of D. Super (1952).

Prospects for further exploration are to establish links between career orientation with meaning-life, value orientations, self-actualization characteristics of students of different professional training and levels of self-actualization. 


\section{References}

Bohatyreva O.O. (2009). Lichnostnye faktory professionalnoi samorealizatsii. Dis. kand. psikhol. nauk [Personal factors of professional self-realization. Dis. PhD in Psychology]. Moskva. 148 p. (In Russian).

Zeer E.F. (1988). Psikhologicheskie osnovy professionalnogo stanovleniia lichnosti inzhenera-pedagoga. Dis. ... d-ra psikhol. nauk [Psychological foundations of the professional formation of an engineer-pedagog personality. Dis. Doctor of Psychology]. Sverdlovsk. 356 p. (In Russian).

Ilhunova O.E. (2005). Dinamika stanovleniia stilei professional'noi deyatel'nosti na raznykh etapakh kar'ery gosudarstvennykh sluzhashchikh. Dis. kand. psikhol. nauk [Dynamics of the formation of professional activity styles at different stages of the public servants'career. Dis. PhD in Psychology]. Moskva. 197 p. (In Russian).

Klimov E.A. (1996). Psikhologiia professionalizma [The psychology of professionalism]. Moskva: Znanie. 95 p. (In Russian).

Kondakov I.M., Sukharev A.V. (1989). Metodologicheskie osnovaniia zarubezhnykh teorii professional'nogo razvitiia [Methodological foundations of foreign theories of professional development]. Voprosy psikhologii [Psychology issues], no. 5. 158-164 pp. URL: http://www.voppsy. ru/issues/1989/895/895158.htm (Accessed: 13 July 2020). (In Russian).

Krichevskii R., Siniagin Iu. (2012). Menedzhment i samomenedzhment karery [Management and self-management of the career]. Munitsipalnaia sluzhba. Institut munitsipalnogo upravleniia [Municipal service. Institute of Municipal Management], no. 1. 89-97 pp. URL: https://rucont.ru/efd/220479 (Accessed: 10 July 2020). (In Russian).

Ladanov I.D. (1997). Psikhologiia upravleniia rynochnymi strukturami: Preobrazuiushchee liderstvo [Psychology of market structure management: Transformative Leadership]. M.: UTs "Perspektiva”, 288 p. (In Russian).

Markova A.K. (1996). Psikhologiia professionalizma [Psychology of professionalism]. M.: Nauka, 308 p. (In Russian).

Melnikova N.N. (2012). Karernaia napravlennost: vektornaia model diagnostiki i interpretatsii [Career trend: a vector model of diagnosis and interpretation]. European Social Science Journal. № 2. 270-277 pp. (In Russian).

Mitina L.M. (2009). Psikhologicheskiie osnovy professionalnogo razvitiia lichnosti v sisteme "chelovek-obrazovanie-professiia" [Psychological foundations of the professional development of personality in the system of "human-education-profession"]. "Chelovek-obrazovanie-professiia”: materialy V mezhdunar. nauch.-prakt. konf., g. Moskva, 6-8 iiulia 2009 g. ["Human-education-profession": materials of the Vint. scientific and practical conf., Moscow, July 6-8, 2009]. Moskva: RAO, MGPPU. 10-15 pp. (In Russian).

Mohilevkin E.A. (1998). Lichnostnye faktory professionalnoy karery gosudarstvennykh sluzhashchikh [Personal factors of the professional career of civil servants]. Avtoref. kand. psikhol. nauk [Dissertation abstract of PhD in Psychology. dis.]. Moskva. 24 p. (In Russian).

Povarenkov Iu.P. (2009). Periodizatsiia professionalnogo stanovleniia i realizatsii subiekta truda [Periodization of the professional formation and realization of the subject of labor]. "Chelovek-obrazovanie-professiia": materialy V mezhdunar. nauch.-prakt. konf., g. Moskva, 6-8 iiulia 2009 g. ["Human-education-profession": materials of the V int. scientific and practical conf., Moscow, July 6-8, 2009]. Moskva: RAO, MGPPU. 18-22 pp. (In Russian).

Ponomarev Ia.A. (1983). Metodologicheskoe vvedenie v psikhologiiu [Methodological introduction to psychology]. M.: Politizdat, 206 p. (In Russian). 
Potebnia A.A. (1993). Mysl' i iazyk [Thought and language]. K.: SINTO. 92 p. (In Russian). Sovremennyi slovar inostrannykh slov [Modern dictionary of foreign words]. Pod red. L.M. Bash, A.V. Bobrova i dr. [Under the editorship of L.M. Bash, A.V. Bobrov et al.]. M.: Russkii iazyk, 1999. 740 p. (In Russian).

Kibanova A.Ia. (210). Upravlenie personalom v organizatsii [Human resource management in the organization]. M.: Infra-M. 295 p. (In Russian).

Khaken H. (1980). Sinergetika [Synergetics]. M.: Mir. 404 p. (In Russian).

Khammer Ia.S. (2008). Professionalnyi uspekh i ego determinanty [Professional success and its determinants]. Voprosy psikhologii [Psychology issues], no. 4. 147-153 pp. (In Russian).

Khorni K. (1997). Nevroz i lichnostnyi rost: Borba za samorealizatsiiu [Neurosis and personal growth: Struggle for self-realization]. SPb.: Vostochno-Evropeiskii institut psikhoanaliza; BSK. 316 p. (In Russian).

Shchelokova E.G. (2012). Tsennostno-smyslovoe soderzhanie karernoi napravlennosti [Value-semantic content of career orientation]. Dissertatsionnaia rabota kand. psikhol. nauk [Dissertation of PhD in Psychology]. M. 24-250 pp. (In Russian). 